\title{
Influence of Social Media on Youngsters: A Case Study in GC Women University Sialkot, Pakistan
}

\author{
Mahwish Rabia1, Samreen Adnan1, Nadia Misbah1, Humma Nawaz1, Maida Gillani1, \\ Amna Arshad2
}

${ }^{1}$ Department of Statistics, GC Women University, Sialkot, Pakistan

${ }^{2}$ Department of Computer Science, GC Women University, Sialkot, Pakistan

Email: Mahwish.rabia@gcwus.edu.pk

How to cite this paper: Rabia, M., Adnan, S., Misbah, N., Nawaz, H., Gillani, M., \& Arshad, A. (2020). Influence of Social Media on Youngsters: A Case Study in GC Women University Sialkot, Pakistan. Creative Education, 11, 285-296

https://doi.org/10.4236/ce.2020.113022

Received: January 18, 2020

Accepted: March 13, 2020

Published: March 16, 2020

Copyright (c) 2020 by author(s) and Scientific Research Publishing Inc. This work is licensed under the Creative Commons Attribution International License (CC BY 4.0).

http://creativecommons.org/licenses/by/4.0/

\begin{abstract}
Social media have become prominent part of life for many young people today. Social networking sites provide a platform for discussion on hot issues that have been overlooked in a day to day basis. The use of information technology in social media has increased its popularity among the youth, especially among the students of universities. Most people engage with social media without stopping to think what the effects are on our lives, whether positive or negative. The current study is conducted to monitor the impact of social media on youth. It is survey-type research where for analyzing the effect of social media on youth the questionnaire study is designed and by using simple random sampling 375 students are selected from GC Women University Sialkot. In this study, it is observed that $59 \%$ of respondents strongly agree that social media is helpful to create awareness among youth whereas $89 \%$ respondents agree that it helps to search jobs for youth. Whereas, $96 \%$ respondents agree that social media is helpful to get knowledge about current affairs of country. On the other hand, considering disadvantages of media, $93 \%$ of respondents agree that too much use of social media causes health problem and $94 \%$ respondents agree that unwanted information creates confusion in the minds of youth, $91 \%$ respondents agree that irrelevant and anti-religious posts and links create hate among people of different communities. The results revealed that social networking sites have the positive as well as negative impact on youth and it is suggested that government and private institutions both should have to work to promote social media's positive activities among youth.
\end{abstract}

\section{Keywords}

Social Media, Society, Institutions, Professional Development of Students, Correlation, Regression Analysis, Youth, Health Problems, Influence of Networking Sites 


\section{Introduction}

Social media is defined as a collection of applications such as (Facebook, Twitter, Youtube, Whatsapp, Viber, Messenger, Instagram). The use of the internet is increasing day by day with high rate all over the world. Majority of youth including television viewers and radio listeners are now moving from electronic media to social media. The Internet has linked people together to share the information and aware of other people with their viewpoint or to take part in social networking. It is social media that has shortened the distance and brought the people closer.

The social networking sites have become more common than ever in modern times. These sites have directly influenced the behavior of people, especially on youngsters. There are many benefits that can be associated with these sites but at the same time the most disturbing situation is that young people have seen to be lonelier in their own world and they don't know how to interact with society. As a result, they lose their connection with their own family as well as they lose their communication skills gradually. Youngsters are highly addicted to social media sites as they spend a lot of time on the internet to update status on these social sites, select a picture to change their profile picture, post on walls, and even whatever they make. They make their standard of popularity by their "Likes", the more they have "Likes" they consider that they are more popular in people.

Shrestha lucky (2013) described that social media is a means of connection among people in which they exchange, create and share info and thoughts in virtual communities and networks (Shrestha lucky 2013). It has many advantages on the same channel such as communicating, texting, images sharing, audio and video sharing, fast publishing and linking with all over the world. As the youth rate of using social media is becoming high so as the impact of social media on youth is also going to be high day by day. Due to the extensive involvement of social media in youths' life, it is affecting human behaviors and their lifestyles. The current study focuses on to find out both the positive and negative impact of social media on youth.

Livingstone and Bober (2005), examined that social media has an influence on the teenagers in different methods. For example, while revealing the problematic elements, it has been noticed that how the internet has changed the way of showing graphics that is playing the role to affect the youth negatively. Due to the internet facility, persons have now wider probability to retrieve sexual excitement out of their edge or by chance. Experimentation has displayed that 57\% of 9 to 19 years old have become a connection with online sexual excitement sites. Their experiences with sexual excitement happened occurred through different means; the frequent usual suddenly appeared, opening vulgarity sites by chance while gazing for something else or through links usually in spam emails. Also $22 \%$ of 9 to 19 years historic and weekly younger have by chance turn on a site with brutal or fearful images and $9 \%$ on a site that is aggressive or horrible to a class of younger. Wiley and Sission (2006), reported that the utilization of social sites is almost omnipresent. For instance, a large survey of collage students from several universities in the Midwest U.S. found that $91 \%$ of respondents use 
the site Facebook.com. Most of the students originally activated their Facebook accounts during the summer before college (53.26\%), though some did so after they began college (38.04\%). On average, respondents had been using Facebook for about 2 years $($ Mean $=24.32$ months, Standard deviation $=9.93)$. Only students who had a Facebook account participated in this study, but almost all of the students in the classes were members of Facebook. Nielsen (2009) examined that in the United State among 33 million digital citizens have age between 10 to 19 years, $90 \%$ have interaction to the internet at home, and $73 \%$ have interaction on a school computer. On average, U.S youth spend 24 hours and 54 minutes a month on the web or to manipulate internet-provider program. And what they're performing online is not a secret; $68 \%$ of youths description reveals interacting with mobile videos with $54 \%$ of these youth manipulating their phones to download and look at songs content. Almost halfway of online youths 12 to 17 of them visited MySpace or Facebook in May 2009, consider for 28\% of MySpace's page views and 12\% of Facebook's during that time. Kirschner and Karpinski (2010), examined the connection between educational achievement and Facebook utilization. The sample was chosen from the population of 219 university students and they introduced that Facebook users had less grade point averages as they were online most of the time. Only $26 \%$ of students announced that social networking sites influenced strongly and assisted to get positivity in their lives and $74 \%$ said that it had an unfavorable impact like postponing something, absence of attentiveness or interruption and going over of controlling things or people. Dahlstrom et al. (2011), stated that on the opposite, few writers and researchers beat dispute with the antecedent declaration, like Hart et al. (2010), Tiryakioglu and Erzurum (2010), Chen \& Brayer 2010 speaks that regardless of the using social media for private utilization only short portion of undergraduates and departments have use them for educational exercises. Online social networking sites, such as Facebook, Twitter \& MySpace are used on a regular foundation by many millions of youth. The adulthood of these online networking sites is majority the college youth. A new survey of 3000 students from across the US has shown that 90\% of college youth use Facebook and 37\% use Twitter. Jain et al. (2012) explained that the survey elucidates that men spend more time as compared to women on social networking sites to review the current social issues and yet women are very sensitive to such issues. The youth takes active participation and raises their voices to express their opinions and views on social issues being discussed on these social networking sites. Also, the findings have shown that even though the youth reciprocates to these events they still do not take up discussions beyond the web and forget about them once they sign off. Thereby, these sites prove to be a boon to the youth in terms of spreading awareness about these issues that arise. Rabia et al., (2019) examined the impact of media on the student's academic performance. The data was collected using questionnaire and analyzed through statistical package for social sciences (SPSS). The results demonstrate that 183 (67\%) respondents agreed that students waste much time on social media. Yousaf et al., (2019) investigated that 
technology can have large impact on user mental and physical health. The data was collected using survey method and sample of 373 students are taken from GC Women University Sialkot. The significant results show that technology has positive effect as well as negative effects on youth.

\section{Research Methodology}

\subsection{Population}

In the present study, the population is considered from Govt. Collage Women University Sialkot. The total number of students in Govt. Collage Women University Sialkot is 6000 .

\subsection{Sample}

Using the formula provided by Yamane (1967). Where " $N$ " is the total population size and " $e$ " is the margin of error, a sample of size 375 is determined from the given population. The procedure is given below:

$$
\begin{gathered}
n=\frac{N}{1+N e^{2}} \\
n=\frac{6000}{1+6000(0.05)^{2}}=375
\end{gathered}
$$

\subsection{Sampling Technique}

Simple random sampling is used to select sample.

\subsection{Analysis of Data}

The following statistical techniques are used to analyze the data:

1) Graphs and Frequency Distribution;

2) Correlation Coefficient;

3) Mann Whitney U-Test (Alternative to t-test);

4) Regression Analysis.

\section{Significance of the Study}

1) To find out the behavior of youth towards social media.

2) To examine whether there is any negative impact of social media on youth.

3) To find out the opinions of youth about social media networking sites.

4) To examine whether social media is unavoidable for youth.

5) To suggest different ways of removing negativity about social media and provide social media for positive purposes (Like study and awareness).

\section{Results and Interpertations}

Figure 1 illustrates that $4 \%$ of respondent are from the $1^{\text {st }}$ semester, $10.1 \%$ of them are from the $3^{\text {rd }}$ semester and $10.6 \%$ of them are from the $5^{\text {th }}$ semester and $8.5 \%$ of them are from the $7^{\text {th }}$ semester. Figure 2 shows that $21.2 \%$ of the respondent are of 17 - 20 years old and 12\% are from 20 - 24 years old. Moreover, 


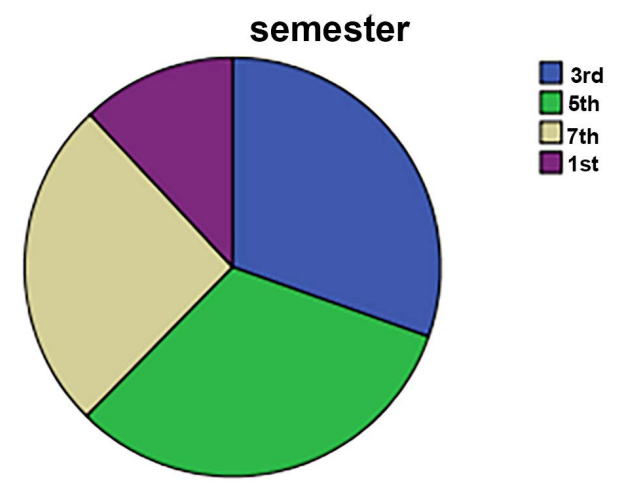

Figure 1. Semester representation of respondents.

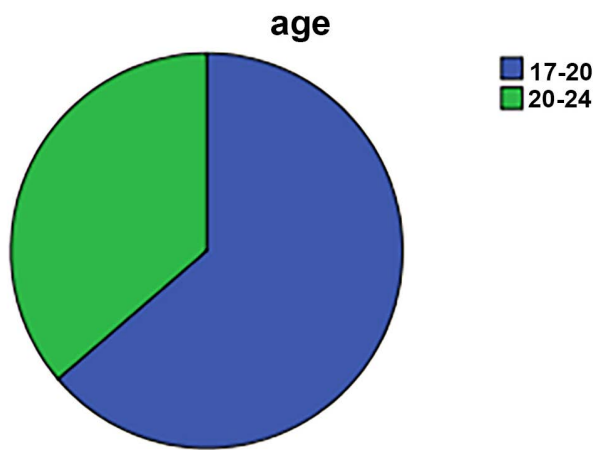

Figure 2. Age representation of respondents.

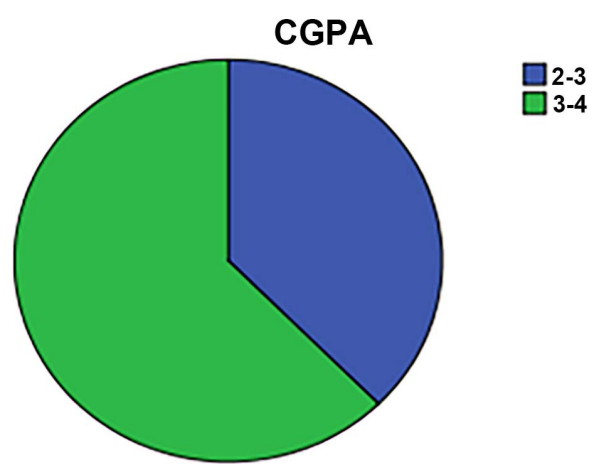

Figure 3. CGPA representation of respondents.

Figure 3 displays that $12.5 \%$ of the respondents have CGPA between 2 - 3 and $20.7 \%$ of them have CGPA between 3 - 4 .

Table 1 illustrates well that $1.9 \%$ of the candidates are Facebook users, $6.7 \%$ are Instagram users, $60.0 \%$ are Whatsapp users, $0.5 \%$ are twitter users and 30.9\% use all of these. $44.5 \%$ of respondents spend $1-2$ hours, $30.1 \%$ of respondents spend 3 - 4 hours and $25.3 \%$ of them spend more than 4 hours on these social networking sites. $16 \%$ of the candidates use social networking sites to keep up for different activities like news, gossips and trends, 5.1\% of them use to feel a sense of belonging or to interact with new people, $36.5 \%$ of them use to contact with family/friends, $10.4 \%$ of them use to raise awareness, and $27.7 \%$ of respondents use all these options. 
Table 1. Frequency distribution.

\begin{tabular}{|c|c|c|c|}
\hline \multirow{5}{*}{ Which social networking sites do you use? } & Face book & 7 & 1.9 \\
\hline & Instagram & 25 & 6.7 \\
\hline & WhatsApp & 225 & 60.0 \\
\hline & Twitter & 2 & 0.5 \\
\hline & All of these & 116 & 30.9 \\
\hline \multirow{3}{*}{ How many hours a day do you spend on these sites? } & $1-2$ hours & 167 & 44.5 \\
\hline & 3 - 4 hours & 113 & 30.1 \\
\hline & $>4$ hours & 95 & 25.3 \\
\hline \multirow{6}{*}{ Why you use these social networking sites? } & Keep up with news/gossips/trends & 60 & 16.0 \\
\hline & $\begin{array}{l}\text { To feel a sense of belonging or to } \\
\text { interact with new people }\end{array}$ & 19 & 5.1 \\
\hline & Contact with family/friends & 137 & 36.5 \\
\hline & Sharing/liking posts & 16 & 4.3 \\
\hline & Raise awareness & 39 & 10.4 \\
\hline & All of these & 104 & 27.7 \\
\hline \multirow{5}{*}{ What are personal benefits of using social networking sites? } & Help in studies & 47 & 12.5 \\
\hline & Staying connected with people & 36 & 9.6 \\
\hline & Learn new skills & 32 & 8.5 \\
\hline & Entertainment & 47 & 12.5 \\
\hline & All of these & 213 & 56.8 \\
\hline \multirow{6}{*}{ What do you believe are the disadvantages of using social networking sites } & Cyber bullying & 12 & 3.2 \\
\hline & Headache-eye problem & 96 & 25.6 \\
\hline & Less social interaction & 9 & 2.4 \\
\hline & Time consuming & 81 & 21.6 \\
\hline & Negative feelings/emotions & 6 & 1.6 \\
\hline & All of these & 171 & 45.6 \\
\hline \multirow{4}{*}{ Do you think that privacy policies are effective in social networking sites? } & Strongly agree & 82 & 21.9 \\
\hline & Agree & 224 & 59.7 \\
\hline & Disagree & 59 & 15.7 \\
\hline & Strongly disagree & 10 & 2.7 \\
\hline \multirow{4}{*}{$\begin{array}{l}\text { Do you think that social media is helpful to get knowledge about current } \\
\text { affairs of country? }\end{array}$} & Strongly agree & 173 & 46.1 \\
\hline & Agree & 187 & 49.9 \\
\hline & Disagree & 13 & 3.5 \\
\hline & Strongly disagree & 2 & 0.5 \\
\hline \multirow{3}{*}{ Do you accept friend request from strangers? } & Yes & 13 & 3.5 \\
\hline & Sometimes & 61 & 16.3 \\
\hline & No & 301 & 80.3 \\
\hline
\end{tabular}




\section{Continued}

\begin{tabular}{|c|c|c|c|}
\hline \multirow{4}{*}{ Do you think that social media is helpful to create awareness among youth? } & Strongly agree & 221 & 58.9 \\
\hline & Agree & 123 & 32.8 \\
\hline & Disagree & 20 & 5.3 \\
\hline & Strongly disagree & 11 & 2.9 \\
\hline \multirow{4}{*}{ Do you think that social media helps to search jobs for youth? } & Strongly agree & 124 & 33.1 \\
\hline & Agree & 211 & 56.3 \\
\hline & Disagree & 24 & 6.4 \\
\hline & Strongly disagree & 16 & 4.3 \\
\hline \multirow{4}{*}{$\begin{array}{l}\text { Do you think that irrelevant and anti-religious post and link create hatred among } \\
\text { people of different communities? }\end{array}$} & Strongly agree & 149 & 39.7 \\
\hline & Agree & 192 & 51.2 \\
\hline & Disagree & 24 & 6.4 \\
\hline & Strongly disagree & 10 & 2.7 \\
\hline \multirow{4}{*}{ Do you think that too much use of social media causes health problem? } & Strongly agree & 191 & 50.9 \\
\hline & Agree & 159 & 42.4 \\
\hline & Disagree & 15 & 4.0 \\
\hline & Strongly disagree & 10 & 2.7 \\
\hline \multirow{4}{*}{ Do you think that social media is necessary for youth? } & Strongly agree & 80 & 21.3 \\
\hline & Agree & 245 & 65.3 \\
\hline & Disagree & 38 & 10.1 \\
\hline & Strongly disagree & 12 & 3.2 \\
\hline \multirow{4}{*}{ Do you think that unwanted information create confusion in the minds of youth? } & Strongly agree & 155 & 41.3 \\
\hline & Agree & 198 & 52.8 \\
\hline & Disagree & 11 & 2.9 \\
\hline & Strongly disagree & 11 & 2.9 \\
\hline
\end{tabular}

Meanwhile, $12.5 \%$ of the candidates believe that the media help in studies is one of the personal benefits of using social networking sites, $9.6 \%$ of them believe staying connected with people, $8.5 \%$ of them believe to learn new skills from social media, $12.5 \%$ of them believe entertainment, $56.8 \%$ believe all of these options are personal benefits of using social networking sites. $46.1 \%$ are strongly agreed, $49.9 \%$ are agreed, $3.5 \%$ disagreed, $0.5 \%$ are strongly disagreed that social media is helpful to get knowledge about current affairs of the country. $32.8 \%$ are strongly agreed, $58.9 \%$ are agreed, $5.3 \%$ disagreed, $2.9 \%$ are strongly disagreed that social media helps to spread awareness among youth. $33.1 \%$ are strongly agreed, $56.3 \%$ are agreed, $6.4 \%$ disagreed, $4.3 \%$ are strongly disagreed that social media helps to search for jobs. $21.3 \%$ are strongly agreed, $65.3 \%$ are agreed, $10.1 \%$ disagreed, $3.2 \%$ are strongly disagreed that social media is necessary for youth.

In addition, 3.2\% of the candidates believe that cyberbullying is the disadvantage of using social networking sites, $25.6 \%$ of them believe that headache-eye 
problem caused due to the extensive use of social media, $2.4 \%$ of them believe less social-interaction, $21.6 \%$ of them believe that social media is time-consuming, $1.6 \%$ of them believe that social media give rise to negative feelings and emotions, $45.6 \%$ of them believe all of these options are disadvantages of using social networking sites. $21.9 \%$ of respondents are strongly agreed, $59.7 \%$ are agreed, $15.7 \%$ disagreed, $2.7 \%$ are strongly disagreed that privacy policies are effective in social networking sites. 3.5\% of the candidates accept a friend request from strangers, $16.3 \%$ are those that accept sometimes, $80.3 \%$ are those who never accept friend requests from strangers.

Moreover, $39.7 \%$ are strongly agreed, $51.2 \%$ are agreed, $6.4 \%$ disagreed, $2.7 \%$ are strongly disagreed that anti-religious posts and links create hatred among people of different communities. $50.9 \%$ are strongly agreed, $42.4 \%$ are agreed, $4 \%$ disagreed, $2.7 \%$ are strongly disagreed that too much use of social media causes a health problem.41.3\% are strongly agreed, $52.8 \%$ are agreed, $2.9 \%$ disagreed, $2.9 \%$ are strongly disagreed that unwanted information creates confusion in the minds of youth.

\subsection{Relationship between Variables}

In this study value of correlation coefficient is calculated, to test the relationship between two variables.

From Table 2, the value of correlation coefficient $(r=0.217, p$-value $=0.000<\alpha)$ which means that there is a direct (positive) relationship among awareness and to search job for youth in social media. It demonstrates that if the youth use more social media networking sites then it will play a vital role for youth to get awareness about new ideas, opportunities, work experiences and new techniques for finding jobs. In other words, social media is a tool that can enhance the job opportunities for youth through identifying their target, create a persuasive marketing campaign, stay motivated and organized. Furthermore, if there is lack of awareness of the social media, people may not get a chance to have golden job opportunities.

Meanwhile, the value of correlation coefficient $(\mathrm{r}=0.162, p$-value $=0.002<\alpha)$ demonstrates that there is a direct (positive) relationship among the privacy

Table 2. Correlation between variables.

\begin{tabular}{lccc}
\hline \multicolumn{1}{c}{ Attributes } & $\begin{array}{c}\text { Correlation } \\
\text { Coefficient }\end{array}$ & P-value & Conclusion \\
\hline $\begin{array}{l}\text { 1) Social media is helpful to create awareness among } \\
\text { youth 2) Social media help to search job for youth }\end{array}$ & $0.217^{*}$ & 0.000 & Significant \\
$\begin{array}{l}\text { 1) Privacy policies are effective in social networking } \\
\text { sites 2) Social media is helpful to get knowledge about } \\
\text { current affairs }\end{array}$ & $0.162^{*}$ & 0.002 & Significant \\
$\begin{array}{l}\text { 1) Social media is helpful to create awareness among } \\
\text { youth ii. Unwanted information create confusion in } \\
\text { the minds of youth }\end{array}$ & $0.149^{*}$ & 0.004 & Significant \\
$\begin{array}{l}\text { 1) Which social networking sites people use 2 Time } \\
\text { spend on networking sites (hours a day) }\end{array}$ & $0.209^{*}$ & 0.000 & Significant
\end{tabular}

${ }^{*}$ P-value Significant at $5 \%$ margin of error $(\alpha=0.05)$. 
policies and knowledge about current affairs. It means that social media is helpful to get awareness about current affairs like analysis of current issues, including political or industrial controversies. But it can also affect the privacy policies because present time people are persistent of split everything like split location and contact numbers in social networking sites. However, if youth sharing their data for getting knowledge about current affairs then sometimes their privacy policies may be affected in social networking sites.

Furthermore, the value of correlation coefficient $(\mathrm{r}=0.149, P$-value $=0.004<$ a) reveals that there is a direct (positive) relationship between spreading awareness among youth and unwanted information create confusion in the minds of youth. It illustrates that social media facilitates in split information, proposal, and profession interests and other formation. It can also create awareness among youth i.e. social media grow the online social media by attachment of a user's profile with those of other persons or groups. We can also find out that there is a difficulty in understanding issues and effectively making decisions when one has too much information about specific topics like religion conflicts, domestic violence, and terrorism etc. Consequently, due to extensive information, it sometimes becomes difficult to take quality decisions.

In addition, the value of correlation coefficient $(r=0.209, P$-value $=0.000<\alpha)$ shows that there is direct (positive)relationship between which social networking site people use and time spend on networking sites. It demonstrates that youth use many social networking sites for their daily life work and entertainment such as Whatsapp, Facebook, Instagram and Twitter etc. They use these sites for communication, awareness, study purpose and sharing posts about their interesting topics etc. Moreover, youth prefer their favourite networking site so that they spend their quality time on that networking site.

To check the significance of variables, discrimination between the impact of social media on youth and youth behavior toward social networking sites, the Mann-Whitney test is applied. The main objective is to check the point of view of youth on these variables.

Table 3 checks the significance of variables; the impact of social networking sites on personal benefits and the privacy policies. The main aim is to check the opinion of youth on these variables. From the provided evidence as our $p$-value is $0.000<0.05$, so we reject the null hypothesis $\left(H_{0}\right)$ and we concluded that the opinion of youth is not same for these variables. In other words, it is considered that the social networking sites are good for personal benefits but privacy policies are also effective in these networking sites.

Table 3. MANN-Whitney U test.

\begin{tabular}{lccc}
\hline \multicolumn{1}{c}{ Attributes } & $\begin{array}{c}\text { MANN-Whitney } \\
\text { Value }\end{array}$ & P-value conclusion \\
\hline $\begin{array}{l}\text { 1) Personal benefits of social networking sites } \\
\text { 2) Privacy policies are effective in social networking sites }\end{array}$ & $23,717.000$ & 0.000 & significant \\
\hline
\end{tabular}




\subsection{Regression Analysis}

In this study, multiple linear regression analysis has been conducted, to determine the value of a variable based on the value of two or more other variables. The variable we want to predict is called the response variable. The variable we are using to predict the value of the response variable is called the explanatory variables. In regression coefficient of determination determines how much change in the response variable is examined by the explanatory variables.

\section{Multiple Regression Model is defined as:}

$$
Y=\beta_{0}+\beta_{1} x_{1}+\beta_{2} x_{2}+e
$$

where $\beta_{0}$ is intercept and $\beta_{1}, \beta_{2}$ are slopes of model.

$Y=$ Social media is necessary for youth.

$x_{1}=$ Social media is helpful to create awareness among youth.

$x_{2}=$ People use social networking sites (facebook, instagram, twitter, whatsapp).

Table 4. Multiple linear regression mode.

\begin{tabular}{|c|c|c|c|c|}
\hline Predicator Variable & $\beta$ & S.E & $\mathrm{t}$ & p-value \\
\hline (constant) & 1.426 & 0.126 & 11.353 & 0.000 \\
\hline $\begin{array}{c}\text { Social media is helpful to create } \\
\text { awareness among youth }\end{array}$ & 0.206 & 0.056 & 3.708 & 0.000 \\
\hline $\begin{array}{c}\text { People use social networking site } \\
\text { (whatsapp, twitter, facebook, instagram) }\end{array}$ & 0.61 & 0.023 & 2.684 & 0.008 \\
\hline \multicolumn{2}{|l|}{$R^{2}=0.53$, S.E $=0.785$} & \multicolumn{3}{|c|}{$\mathrm{F}=10.326, p$-value $=0.000$} \\
\hline \multicolumn{5}{|c|}{$Y=1.426+0.206 x_{1}-0.61 x_{2}$} \\
\hline
\end{tabular}

In Table 4 the value of $\mathrm{R}$-square 0.53 indicates that $53 \%$ variation is explained by the explanatory variables. The multiple regression model represented by Equation (3) is based on two explanatory variables and one response variable. The response variable is social media is necessary for youth and the explanatory variablescreate awareness among youth and people use social networking sites. Also, all the regression parameters $\left(\beta_{0}=1.426, \beta_{1}=0.206, \beta_{2}=0.61\right)$ are significant i.e. $p$-value is less than the significance value $(\alpha=0.05)$. The fitted multiple regression model display that social media is necessary for youth to spread awareness and also the youth uses these networking sites more frequently because they consider them necessary for themselves.

\section{Conclusion}

This paper looks over the effect of social media on youth. The use of social networking sites among youth is increasing day by day. The current research work perceived that people use Facebook, Instagram, WhatsApp and Twitter to connect with family members and friends. Almost everybody has at least one account on a social networking website. The results revealed that $45 \%$ respondent spend 1 - 2 hours and $30 \%$ spend 3 - 4 hours on social networking sites. Mostly 
respondents use social networking sites to feel a sense of belonging or to interact with new people, keeping up with news, gossips or trends, contacting with family and friends, sharing and liking interesting posts and raising awareness. The results of correlation coefficient demonstrate that the media plays an important role in society, it creates awareness, is helpful to search jobs and to get knowledge about current affairs. Moreover, it has positive as well as negative impact on Youth. On one side, people use it for learning and finding job opportunities but on the other hand it also has disadvantages like Cyber bullying, headache, less social interaction, time consuming and negative feelings or emotions. As a result, it affects health and education of students.

\section{Suggestions}

Considering the current survey and results, the research suggests a few instructions that are as follows:

1) The use of social media should be in a way that proved to be appreciative and appropriate among its user.

2) When youth interact with social media, they should keep in mind that social networking sites are not just for satisfaction and attractiveness but also for enhancing communication skills and can be used for study purpose.

3) Social media should be used for constructive motives.

4) The use of social media for communication increases the users' expertise and capabilities.

5) To reduce its pessimistic results, government must have to take some important steps. The government should prohibit unethical websites.

6) Powerful guidance for the Government is to make a strategy or group that investigates which unethical websites are used by the users.

7) A powerful guidance for the users of social media is that they have to recall the motive of social media and always use the instructional sites.

8) Parents and teachers should keep an eye on youth to check for which activities students are using social media.

\section{Conflicts of Interest}

The authors declare no conflicts of interest regarding the publication of this paper.

\section{References}

Dahlstrom, E., Deboor, T., Grunwald, P., \& Vockley, M. (2011). ECAR: National Study of Undergraduate Students \& Information Technology.

Dan, S. (2013). The Impact of Social Media on Youth: A Case Study of Bahawalpur City. The Hidden Impact of Social Media. Bigger, 3, 132-134.

Jain, M. R., Anand, N., \& Gupta, P. (2012). Impact of Social Networking Sites in the Changing Mindset of Youth on Social Issue: A STUDY to Delhi-NCR youth. Journal of Arts, Science and Commerce, 3, 36-43.

Kirschner, P. A. \& Karpinski, A. C. (2010). Face Book \& Academic Performance. Com- 
puters in Human Behavior, 26, 1237-1245. https://doi.org/10.1016/j.chb.2010.03.024

Livingstone, S. M., \& Bober, M. (2005). Department of Media \& Communications, London School of Economics \& Political Science (pp. 3-13). UK Children Go Online: Listening to Young People's Experiences.

Nielsen Company (2009). How Teens Use Media: A Nielsen Report on the Myths \& Realities of Teen Media Trends. Retrieved September, 29, 2010.

Rabia, M., Nawaz, H., Mubarak, N., \& Ali, S. Z. (2019). Impact of Media on Academic Performance of College Students: A Case Study of Pakistani Government Colleges. Open Journal of Social Sciences, 7, 429-442.

Wiley \& Sission, M. (2006). Ethics, Accuracy and Assumption: The Use of Face Book by Students and Employers. International Journal of Innovative Research in Computer and Communication Engineering, 3.

Yousaf, T., Rabia, M., Shajhan, A., \& Liaqat, A. (2019). Impacts of Technology on Youth: A Case Study in GC Women University Sialkot, Pakistan. Proc. 15th Islamic Countries Conference on Statistical Sciences, Lahore, Pakistan, December 21-24, 2019, Vol. 34, 169-178. 